\title{
Algae-based biotopes of the Azores (Portugal): spatial and seasonal variation
}

\author{
Francisco M. Wallenstein · Ana I. Neto • \\ Nuno V. Álvaro · Catarina I. Santos
}

Received: 21 December 2006/Accepted: 13 July 2007/Published online: 10 August 2007

(C) Springer Science+Business Media B.V. 2007

\begin{abstract}
The increasing importance of coastal management created the need for a systematic classification and characterization of marine communities. Accurate quantitative methodologies for rocky shore algae-based biotope definition, were developed and tested on the Islands of São Miguel and Santa Maria (Azores). Shores of both islands were surveyed, covering all rocky substrate types. Biotopes were defined by assessing the associated habitat and species characteristics, using ANOSIM and SIMPER analysis, respectively. A total of ten biotopes were identified. Generally both islands' biotopes are characterized by the same taxa/ecological categories, in summer and in winter. However, association between these taxa/ecological categories and the shore height at which they occur differs geographically and temporally. There is a generalized gradual succession of taxa/ecological categories from upper intertidal down to deepest subtidal, although geographical differences occur. Diversity is highest at the landwater interface and decreases towards both extremes (upper intertidal and deepest subtidal level). The strongest evidence of seasonal variation occurs at the upper intertidal. The methodology used proves to be
\end{abstract}

F. M. Wallenstein $(\bowtie) \cdot$ A. I. Neto ·

N. V. Álvaro · C. I. Santos

CIRN and Departamento de Biologia, Secção de Biologia Marinha, Universidade dos Açores, Apartado 1422, 9501801 Ponta Delgada, Acores, Portugal

e-mail: fmacedo@notes.uac.pt effective in broad scale shoreline assessment of biological communities in warm-temperate coastal marine environments, and thus suitable for the purpose it was developed for. As a consequence it should be applied to the remaining islands of the Azorean archipelago as well as to other macaronesian islands, e.g. Madeira and the Canaries.

Keywords Coastal management . Comparative studies $\cdot$ Macaronesia

\section{Introduction}

Environmental management puts increasing demand on spatial surveys of marine benthic habitats and associated biota. Marine environments support a wide array of habitats with diverse associated biotic assemblages. If these are to be protected from adverse effects, their variety, classification and spatial extent must be assessed.

Examples of coastal ecosystem and community classification studies have been developed recently in the EU and USA (Hiscock 1995; Connor et al. 1997, 2004; Mumby and Harborne 1999; Zacharias and Roff 2000; Bartsch and Tittley 2004). Connor et al. (2004) is the most comprehensive of such studies and aims at establishing a set of rules for naming communities and hierarchies of terminology, as are the cases of the phytocoenological approaches to coastal community ecology of Braun-Blanquet 
(1928) for plant communities, and of den Hartog (1959) and den Hartog and Segal (1964) for water plant communities. However, these studies are to some extent descriptive, with somewhat unclear methodologies and are not applicable to warmtemperate/subtropical islands, such as those of the Azorean archipelago.

The Azores are centrally located in the North Atlantic $\left(37^{\circ} 40^{\prime} \mathrm{N}\right.$ and $25^{\circ} 31^{\prime} \mathrm{W}$, Fig. 1), lacking a continental shelf, thus presenting a restricted coastal extension that reaches a depth of 1000 m only $200 \mathrm{~m}$ offshore (Morton et al. 1998), and are exposed to medium/high levels of wave action (Macedo 2002). Shore geomorphology alternates between high cliffs and rocky cobble/boulder beaches (Borges 2004) and tidal range is small $(<2 \mathrm{~m}$, see Instituto Hidrográfico 1981), creating a specific environment for algal communities to develop. As a result, rocky littoral communities of the Azores are dominated by compact mats of turf forming algae (Neto 2000a, 2001). Large canopy-forming brown algae which are characteristic at Northern European sheltered and moderately exposed shores are absent from the Azorean intertidal, where foliose and frondose algae are present only at the lowest level, in the transition to the subtidal, while subtidal algal communities are characterized by large overlapping areas co-dominated by few frondose algal species (Neto 2000a, 2001).

Biotope surveys are recent in the Azores, and Tittley and Neto (2000) and Wallenstein and Neto (2006) are the two first attempts to define habitat- communities associations. These studies have proved the need for further development of clear methodologies for comparability studies. The latter established field methods for intertidal surveys and Wallenstein et al. (2006, in press) further developed field methodologies for subtidal surveys and established precise data analysis procedures for biotope definition. These protocols recognize the need to collect data in a structured and systematic way and establish clear methods for the classification of communities and associated habitat characteristics without requiring the involvement of experienced samplers. The present paper aims at defining and characterizing Azorean algae based biotopes and at allowing spatial and seasonal comparisons of results from a widespread implementation of the above mentioned characterization methodologies. It thus intends to (1) provide a general characterization of Azorean littoral biotopes, (2) test the applicability of methodologies on other islands of the Azorean archipelago, namely in assessing differences among them and thus (3) provide management tools for coastal resource managers in warm-temperate coastal marine environments.

\section{Materials and methods}

Site selection

Rocky shore study sites around the Islands of Santa Maria and São Miguel were selected randomly by
Fig. 1 Map of the Azores archipelago

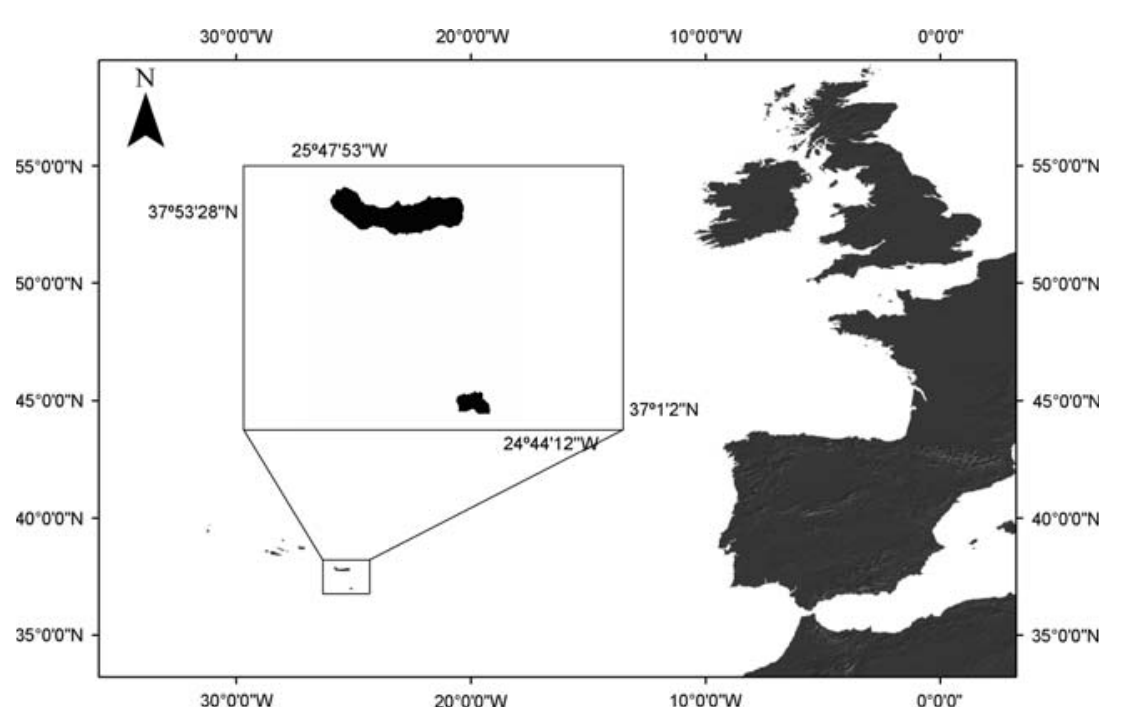


overlaying a $2 \times 2 \mathrm{~km}$ grid on the map of each island; the grid intersections around the coastline created a pool of potential study sites which were numbered and selected using random numbers (see Wallenstein and Neto 2006; Wallenstein et al. 2006 in press). The total number of sites to be studied at the intertidal and the subtidal of each island was defined according to the availability of time for each sampling campaign, covering all substrate types and the whole coast-length.

\section{Intertidal fieldwork}

For spatial variation analysis the two islands were compared. A balanced sampling design was possible for the Island of São Miguel: 18 sites ( 6 cobbles; 6 boulders; 6 bedrock), distributed around the island were surveyed between January and June 2005. In Santa Maria an unbalanced sampling design was used due to low representation of some substrate categories: 15 sites around the island ( 4 cobbles; 3 boulders; 8 bedrock), were surveyed during the month of June 2005.

For seasonal variation analysis of São Miguel's intertidal biotopes two data sets were used: (a) 2001summer dataset from Wallenstein and Neto (2006) and (b) 2004-winter data from the present study. Sampling methods used in the present study are those of Wallenstein and Neto (2006). Stratified random sampling involving quantitative recording of taxal ecological categories (see 'Algae classification' below) along transect lines was used to identify recurrent patterns of algae assemblages.

At low-tide transect lines were laid perpendicularly to the coastline across the intertidal area from the point at which an alga was first observed and extending to low water level. Frequency of occurrence of each taxa/ecological category present in quadrats was taken at five equidistant shore levels: level 1low water level; level 5-where the first alga was observed; level 3-half distance between levels 1 and 5; level 2-half distance between levels 1 and 3; level 4-half distance between levels 3 and 5 .

Surveys were restricted to a single-substratum type at each site, and quantification procedures applied to three transects per site. Five replicate quadrats at each shore level were placed at right angles to the transect line in a direction and distance determined by double-digit random values. For all substratum types quadrats were placed at the upper- or sea-facing sides of the rocky surface.

Frequency recording of sessile organisms was done by a point-to-point method using $0.25 \mathrm{~m} \times 0.25 \mathrm{~m}$ quadrats with 36 intersection points (Hawkins et al. 1990; Neto 1997). Total counts of littorinids, and limpets within each replicate quadrat were also recorded when present.

\section{Subtidal fieldwork}

Following Wallenstein et al. (2006 in press), a stratified sampling design considered depth as a single factor, with four levels: 4-6 m; 12-14 m; 20$22 \mathrm{~m}$; and 28-30 m. Each depth level was replicated with multiple sampling sites, where three replicated recordings were made, corresponding to nine quadrats in total (three replicate readings of three $0.50 \mathrm{~m} \times 0.50 \mathrm{~m}$ quadrats, see Neto 1997), randomly placed around the anchor of the boat at the mid depth of each level $(5,13,21$ and $29 \mathrm{~m})$. Algae, sponges, hydrozoans and bryozoans' frequency was recorded by a point-to-point method using $0.50 \mathrm{~m} \times 0.50 \mathrm{~m}$ quadrats with 36 intersection points (Neto 1997). Macroinvertebrates' frequencies (sea-urchins, seastars, sea-cucumbers, tube worms and fire worms) were recorded within a minimal sampling area of $1.5 \mathrm{~m} \times 15 \mathrm{~m}$ replicated 3 times (see Martins et al. 2005). Due to time and logistic constraints in Santa Maria only four sites were sampled for each depth level, while in São Miguel six sites per depth interval were sampled.

\section{Algae classification}

With the aim of simplifying methodologies biotope complex definition used a wide classification of algae into broad ecological categories: green; turf; and fronds. For biotope definition, a narrower classification of algae was adopted, namely if exhibiting a frondose form they were identified to genus/species level in situ (Laurencia/Osmundea, Stypocaulon/ Halopteris, Dictyota spp., Zonaria tournefortii) and otherwise generically classified as: green algae (Ulva spp., Blidingia spp.); calcareous crusts (grouped with bare substrate as "first stratum"); soft crusts 
(Nemoderma tingitana, Hildenbrandia sp., Ralfisa sp.); erect calcareous (Corallina elongata, Jania spp. and Haliptilon spp. exhibiting an obviously erect growth form); calcareous turf (with erect calcareous species visually dominant, but not exhibiting a frondose growth form) or non calcareous turf (where calcareous species were not visually evident). In order to identify turf constituents of difficult diagnosis in situ, especially in the case of multispecific turfs, samples were collected and a semi-quantitative characterization of constituents conducted in the laboratory using the DAFOR scale.

\section{Data treatment}

Following the methodologies proposed by Wallenstein et al. (2006, in press), taxa/ecological categories absolute frequency was converted into relative frequency for data treatment (frequency of occurrence in each quadrat was divided by the total number of intersections in a quadrat-36). This measure was used to reflect each taxon/ecological category's percentage cover of the substratum. The analytical methods used PRIMER (Clarke and Warwick 2001), and consisted of a sequence of analysis: (1) ANOSIM (non-parametric procedure applied to the rank similarity matrix underlying the ordination of quadrats) to test the significance of differences between samples across shore height levels (intertidal), and between samples across depth levels (subtidal); and (2) SIMPER analysis (species contribution to similarity) applied to untransformed and presence/ absence data, to identify the more relevant taxal ecological categories at each shore level (intertidal) and depth level (subtidal). Taxa/ecological categories relevant for biotope definition were chosen according to two criteria (a: Average Abundance $>0.55$ for presence/absence data; $\mathrm{b}$ : \% Contribution $>9.5 \%$ for untransformed data).

\section{Biotope nomenclature}

Identified biotopes were given code names according to the criteria defined by Connor et al. (2004): L (littoral) for the intertidal zone; I (infralittoral) for the subtidal zone; E for exposed and moderately exposed shores; and R for rocky substrata. Abbreviations for taxa/ecological categories were as follows: $\mathrm{T}$ (Turf); and $\mathrm{F}$ (Fronds - used only in cases, where biotopes are not characterized by a genus/species that names the biotope). Genus/species names were abbreviated to the three initials, and ecological categories abbreviated as follows: green algae (GreA); calcareous turf (CalT); and non calcareous turf (NCalT).

\section{Results}

Spatial variation

The ANOSIM test was performed to identify differences between substrate categories at the intertidal level of both islands (Table 1) revealed significant differences between substrata (both globally and for pairwise tests). Interestingly, $R$ values below 0.1 indicate that differences between both islands (Santa Maria and São Miguel) are near to zero although significant $(0.1 \%<<5 \%)$. Additionally, in both places it is possible to verify that boulders and bedrock are more similar between them than each relative to cobbles $\left(\mathrm{R}_{\mathrm{B}, \mathrm{R}}<\mathrm{R}_{\mathrm{B}, \mathrm{C}} \approx \mathrm{R}_{\mathrm{C}, \mathrm{R}}\right)$.

Global significant differences $(0.1 \%<<5 \%)$ of some magnitude higher than zero (Santa Maria$\mathrm{R}_{\mathrm{SMA}}=0.233$; São Miguel- $\mathrm{R}_{\mathrm{SMG}}=0.216$ ) were found among all shore levels at which sampling was carried out for both islands (Table 2). Significant differences were found between all pairs of shore levels $(\leq 0.6 \%<<5 \%)$. However, these differences are near to zero when considering successive shore levels $\left(\mathrm{R}_{1,2}, \mathrm{R}_{2,3}, \mathrm{R}_{3,4}\right.$ and $\left.\mathrm{R}_{4,5} \approx 0\right)$ which indicates little differences between them. Interestingly these differences are increasingly higher the greater is the distance between two shore levels that are being compared $\left(\mathrm{R}_{1,2}<\mathrm{R}_{1,3}<\mathrm{R}_{1,4}<\mathrm{R}_{1,5} ; \quad \mathrm{R}_{2,3}<\mathrm{R}_{2,4}<\right.$ $\mathrm{R}_{2,5} ; \mathrm{R}_{3,4}<\mathrm{R}_{3,5}$ ).

Subtidally there are significant differences $(0.1 \%<<5 \%)$ among the depth levels at which sampling was carried out (Table 3). These differences are greater in Santa Maria $\left(\mathrm{R}_{\mathrm{SMA}}=0.387\right)$ than in São Miguel $\left(\mathrm{R}_{\mathrm{SMG}}=0.245\right)$. Another striking feature of Table 3 is the fact that for the pairwise comparison of successive depths the major differences are between $13 \mathrm{~m}$ and $21 \mathrm{~m}\left(\mathrm{R}_{13,21}>\mathrm{R}_{5,13}\right.$, $\mathrm{R}_{21,29}$ ) for both islands, although of greater magnitude in Santa Maria. 
Table 1 ANOSIM test to differences between substrate categories (B, boulders; C, cobbles; R, bedrock) at the intertidal of both islands: Santa Maria (Global $\mathrm{R}_{\mathrm{SMA}}=0.082$; significance level $=0.1 \%$; permutations $=999$ random from a large number) and São Miguel (Global $\mathrm{R}_{\mathrm{SMG}}=0.057$; significance level $=0.1 \%$; permutations $=999$ random from a large number)

\begin{tabular}{lllll}
\hline Pairwise tests & \multicolumn{2}{l}{ Santa Maria } & & \multicolumn{2}{l}{ São Miguel } \\
\cline { 2 - 3 } Groups & $R$ Statistic & Signif. level $\%$ & $R$ Statistic & Signif. level \% \\
\hline B, C & 0.09 & 0.1 & 0.076 & 0.1 \\
B, R & 0.068 & 0.1 & 0.03 & 0.1 \\
C, R & 0.098 & 0.1 & 0.068 & 0.1 \\
\hline
\end{tabular}

Table 2 ANOSIM test to differences between shore levels (1, 2, 3, 4 and 5 represent shore levels- "Materials and methods, Intertidal Fieldwork" and Fig. 2) at the intertidal of both islands: Santa Maria (Global $\mathrm{R}_{\mathrm{SMA}}=0.233$; significance level $=0.1 \%$; permutations $=999$ random from a large number) and São Miguel (Global $\mathrm{R}_{\mathrm{SMG}}=0.216$; significance level $=0.1 \%$; permutations $=999$ random from a large number); comparison between successive levels in bold

\begin{tabular}{|c|c|c|c|c|}
\hline \multirow{2}{*}{$\begin{array}{l}\text { Pairwise tests } \\
\text { Groups }\end{array}$} & \multicolumn{2}{|c|}{ Santa Maria } & \multicolumn{2}{|l|}{ São Miguel } \\
\hline & $R$ Statistic & Signif. level \% & $R$ Statistic & Signif. level \% \\
\hline 1,2 & 0.052 & 0.1 & 0.054 & 0.1 \\
\hline 1,3 & 0.245 & 0.1 & 0.27 & 0.1 \\
\hline 1,4 & 0.423 & 0.1 & 0.382 & 0.1 \\
\hline 1,5 & 0.635 & 0.1 & 0.493 & 0.1 \\
\hline 2,3 & 0.086 & 0.1 & 0.108 & 0.1 \\
\hline 2,4 & 0.21 & 0.1 & 0.228 & 0.1 \\
\hline 2,5 & 0.411 & 0.1 & 0.361 & 0.1 \\
\hline 3,4 & 0.034 & 0.2 & 0.041 & 0.1 \\
\hline 3,5 & 0.148 & 0.1 & 0.13 & 0.1 \\
\hline 4,5 & 0.063 & 0.1 & 0.026 & 0.6 \\
\hline
\end{tabular}

Table 3 ANOSIM test to differences between depth levels (5, 13, 21 and 29 represent the depth levels — see "Materials and methods, Subtidal Fieldwork" and Fig. 2) at the subtidal of both islands: Santa Maria (Global $\mathrm{R}_{\mathrm{SMA}}=0.387$; significance level $=0.1 \%$; permutations $=999$ random from a large number) and São Miguel (Global $\mathrm{R}_{\mathrm{SMG}}=0.245$; significance level $=0.1 \%$; permutations $=999$ random from a large number); comparison between successive levels in bold

\begin{tabular}{|c|c|c|c|c|}
\hline \multirow{2}{*}{$\begin{array}{l}\text { Pairwise tests } \\
\text { Groups }\end{array}$} & \multicolumn{2}{|c|}{ Santa Maria } & \multicolumn{2}{|l|}{ São Miguel } \\
\hline & $R$ Statistic & Signif. level \% & $R$ Statistic & Signif. level \% \\
\hline 5,13 & 0.148 & 0.1 & 0.109 & 0.1 \\
\hline 5,21 & 0.877 & 0.1 & 0.358 & 0.1 \\
\hline 5,29 & 0.577 & 0.1 & 0.399 & 0.1 \\
\hline 13,21 & 0.418 & 0.1 & 0.185 & 0.1 \\
\hline 13,29 & 0.24 & 0.1 & 0.219 & 0.1 \\
\hline 21,29 & 0.128 & 0.1 & 0.138 & 0.1 \\
\hline
\end{tabular}

As with the differences between intertidal shore heights, these are lower when analyzing pairwise test results for successive depth levels $\left(R_{5,13}, R_{13,21}\right.$,
$\left.\mathrm{R}_{21,29}<\mathrm{R}_{\mathrm{SMG}}<\mathrm{R}_{\mathrm{SMA}}\right)$, and higher for non successive depth levels $\left(\mathrm{R}_{5,21}, \quad \mathrm{R}_{5,29}>\mathrm{R}_{5,13}\right.$; $\mathrm{R}_{13,29}>\mathrm{R}_{13,21}$ ). 
Fig. 2 Distribution of intertidal and subtidal taxal ecological categories of Santa Maria and São Miguel Islands

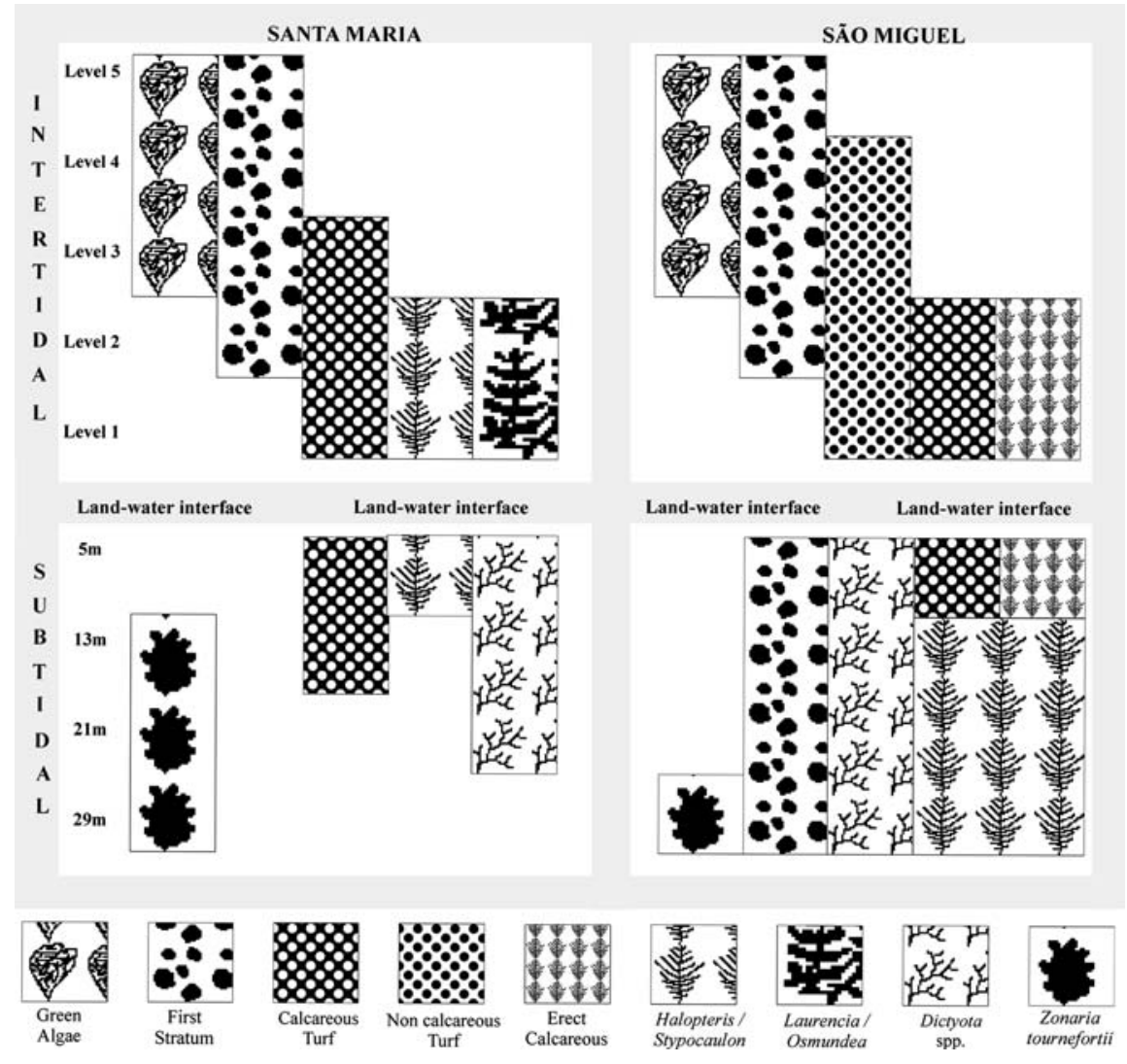

Intertidally and subtidally both islands are characterized by the same ecological categories (Fig. 2) although differences can be identified in the way they are associated. Intertidally a gradient can be observed along the shore height, both for Santa Maria and São Miguel. Differences among these islands occur, though. The presence of green algae at upper levels (levels 5-3) and of free space for colonization-first stratum (rock and/or calcareous crusts)-almost throughout the intertidal (levels 5-2) are the most striking common characteristics. Calcareous turf although present on both islands where it establishes the transition to the subtidal, appears higher on the shore in Santa Maria (level 3 as opposed to level 2 in São Miguel), and penetrates deeper subtidally (13 m depth in Santa Maria as opposed to $5 \mathrm{~m}$ depth in São Miguel). A major difference in the transition to the subtidal (from shore level 2 down to $5 \mathrm{~m}$ depth) occurs between the two islands: Stypocaulon/Halopteris in Santa Maria as opposed to frondose calcareous algae (namely Corallina elongata) in São Miguel. Two other striking differences are: (1) the presence of non calcareous turf in São Miguel almost throughout the whole intertidal (levels 4-1), which is absent in Santa Maria; and (2) the presence of fronds of LaurencialOsmundea at lower levels (levels 1 and 2) in Santa Maria, while absent in São Miguel. Differences between the two islands are more obvious subtidally than intertidally (Fig. 2): (1) Zonaria tournefortii extends from $13 \mathrm{~m}$ down to $29 \mathrm{~m}$ in Santa Maria, while in São Miguel is restricted only to the deepest level $(29 \mathrm{~m})$; (2) the lack of free colonizing space (rock and/or calcareous crusts) in Santa Maria as opposed to São Miguel (present throughout the whole subtidal); and (3) the existence of Stypocaulon/Halopteris down from $13 \mathrm{~m}$ to $29 \mathrm{~m}$ in São Miguel while restricted to shallower water $(5 \mathrm{~m})$ in Santa Maria. The main similarity is the presence of Dictyota spp. on both islands ( $5 \mathrm{~m}$ to $21 \mathrm{~m}$ in Santa Maria opposed to the whole subtidal$5 \mathrm{~m}$ to $29 \mathrm{~m}$ in São Miguel).

The wide classification of algae as green, turf and fronds allows the recognition of a general distribution pattern along the coast that is common to both 
islands, thus the identification of three overlapping biotope complexes: (1) a green algae biotope complex present at the upper and transition intertidal levels; (2) an algal turf biotope complex extending from the transition intertidal level to the shallow subtidal level; and (3) a frondose algae biotope complex extending from the low intertidal level to the deep subtidal level. Considering the gradual natural transition between the intertidal and subtidal zones with lower intertidal algae categories expanding into the shallow subtidal, a total of ten biotopes (Fig. 3) were identified according to the narrower classification of algae into taxa and/or ecological communities associated to rocky substrata at different shore levels: ELR.GreA (Green algae on exposed upper eulittoral rock); ELR.CalTGreA (Calcareous turf and green algae on exposed mid eulittoral rock); ELR.NCalTGreA (Non calcareous turf and green algae on exposed mid eulittoral rock); ELR.CalTF (Calcareous turf and frondose algae on exposed low eulittoral rock); ELR.CalTNCalTF (Calcareous turf, non clacareous turf and frondose algae on exposed low eulittoral rock); EIR.StyCalT (Stypocaulon/Halpteris and calcareous turf on exposed shallow infralittoral rock); EIR.CorCalT (Calcareous fronds and calcareous turf on exposed shallow infralittoral rock); EIR.DicZon (Dictyota spp. and Zonaria tournefortii on exposed mid depth infralittoral rock); EIR.DicSty (Dictyota spp. and Stypocaulon/Halopteris on exposed mid depth infralittoral rock); EIR.Zon (Zonaria tournefortii on exposed deep infralittoral rock).

Striking features of this classification are: (1) the gradient of taxa/ecological categories succession from upper intertidal down to deep subtidal (see

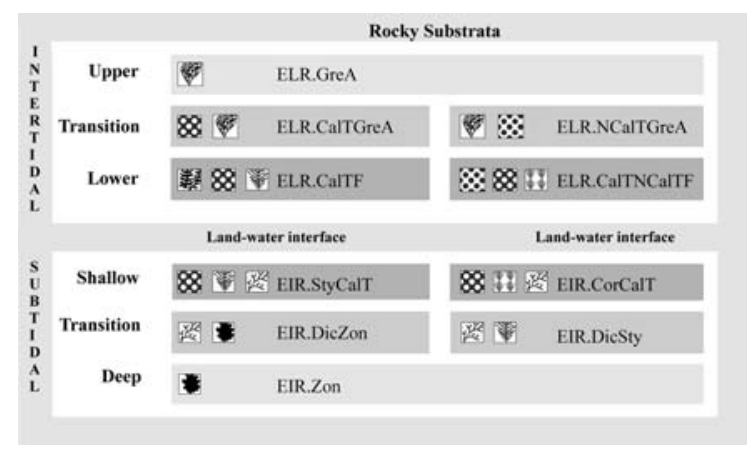

Fig. 3 Rocky shore coastal biotopes of Santa Maria and São Miguel Islands (see description in the text) gradient in Fig. 3); and (2) the increasing number of species as one moves away from the two extremes towards the land-water interface-both extremes characterized by a sole taxon/ecological category, increasing to two and then three taxa/ecological categories when moving down and up to the landwater interface.

\section{Seasonal variation}

The seasonal comparison of the intertidal biotopes for São Miguel Island in the summer and winter periods (summer 2001, data from Wallenstein and Neto 2006; winter, the present study, see Fig. 4) shows that in 2001 the community is composed by four categories (rock, erect calcareous, calcareous and non calcareous turf) whereas in 2004 there is an extra category (green algae).

The intertidal can be divided into three major zones for both years. In 2001: (1) an upper zone characterized by non calcareous turf; (2) a transition zone with erect calcareous and non calcareous turf; and (3) a lower zone composed of erect calcareous and calcareous turf. In 2004: (1) an upper zone characterized by green algae; (2) a transition zone with green algae and non calcareous turf; and (3) a lower zone composed of non calcareous turf, erect calcareous and calcareous turf. Levels 2 and 4 appear to be the transition between levels $1-3$ and $3-5$ respectively, thus presenting communities composed of common categories to both adjacent zones. The most striking differences (Fig. 4) are: (1) the presence of non calcareous turf at upper and transition levels in the summer periods (2001) as opposed to its presence at transition and lower levels in the winter period (2004); and (2) the absence of green algae in the summer periods (2001) as opposed to its presence at upper and transition levels in the winter period (2004). Due to the absence of green algae in 2001, there is no ELR.GreA at the highest shore level and ELR.NCalTGreA at mid shore levels does not include green algae.

\section{Discussion}

Although substrate is considered a major structuring factor in coastal communities (Little and Kitching 
Fig. 4 Distribution of intertidal taxa/ecological categories for São Miguel Island using 2001 and 2004 relative frequency data

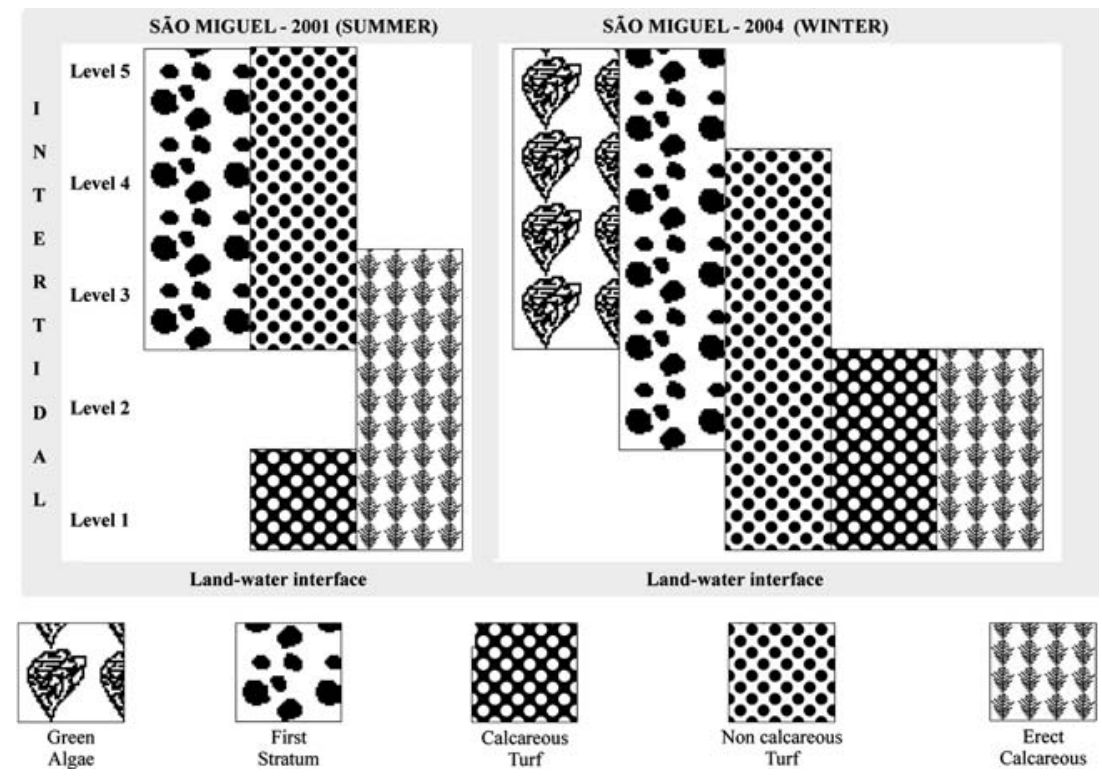

1996), substratum categories seem not to play a determinant role in influencing the biotope composition of the studied Azorean coastal communities as evidenced by $\mathrm{R}$-values from Table 1 . This result is probably the reflex of the methodologies adopted in which macroalgae were classified into broad ecological categories that group taxonomically distant species. The idea behind this decision was to eliminate the noise caused by a large amount of species that share common features and that act as a single ecological entity in terms of community structure (Olenin and Ducrotoy 2006). Additionally, using broad ecological categories is supposed to simplify surveys to be carried out by staff with low taxonomic skills, therefore reducing the need for expert work (Ducrotoy and Simpson 2001). On the other hand, this option is not sensitive to differences between substratum categories that are evidenced when conducting surveys based on species associations, namely between unstable and stable substrata (Wallenstein and Neto 2006). Possibly further research at sub-biotope levels with emphasis on the identification of species within these ecological categories, will extend the classification to include substratum, as a relevant factor.

When comparing increasingly distant shore levels the successively higher values of $\mathrm{R}$, pointout to the transitional nature of communities along a gradient from high intertidal to deep subtidal (Tables 2, 3).
This pattern is evident at both islands and much in accordance with the horizontal distribution pattern of communities described in plenty studies on Azorean coastal communities (e.g. Neto 2000a, 2001; Tittley and Neto 2000).

Intertidally the successive appearance of species from high shore down to water level reflects both the decreasing level of desiccation, and the increasing strength of wave action that algae are subject to. At higher intertidal the green opportunistic and resistant algae dominate together with bare rock and/or calcareous crusts, while at lower intertidal and shallow subtidal turfs prevail. Turfs are physically very resistant to abrasion (wave action) and desiccation (water retention capacity) (Stewart 1989; Neto and Tittley 1995), and thus present a vast distribution along the harshest area of the intertidal/subtidal, while fronds start appearing subtidally where conditions are more favorable for erect morphotypes (Littler and Littler 1980).

Subtidally, increasing depth implies both decreasing light penetration, and decreasing wave influence on communities. Differences were identified at two levels: (1) in terms of coastal vertical distribution reflecting gradients of physical conditions as described above; and (2) in terms of geographically separate areas, namely between the two islands in what concerns the way taxa/ecological categories are distributed and associated. These results reflect that 
Table 4 Comparison of the intertidal biotopes defined for the Azores and the corresponding ones defined by Connor et al. (2004) for the UK

\begin{tabular}{|c|c|c|}
\hline & Azores & Britain \\
\hline Upper eulittoral & $\begin{array}{l}\text { ELR.GreA } \\
\text { Ulva spp. on exposed upper eulittoral rock }\end{array}$ & $\begin{array}{l}\text { MLR.BF PelB } \\
\text { Pelvetia canaliculata and barnacles on moderately exposed } \\
\text { littoral fringe rock } \\
\text { ELR.MB MytB } \\
\text { Mytilus edulis and barnacles on very exposed eulittoral rock } \\
\text { LR.HLR.MusB.Cht } \\
\text { Chthamalus spp. on exposed eulittoral rock } \\
\text { LR.HLR.MusB.Sem } \\
\text { Semibalanus balanoides on exposed to moderately exposed } \\
\text { or vertical sheltered eulittoral rock } \\
\text { ELR.FR Fdis } \\
\text { Fucus distichus and Fucus spiralis f. nana on extremely } \\
\text { exposed upper shore rock } \\
\text { LR.MLR.BF.FspiB } \\
\text { Fucus spiralis on exposed to moderately exposed upper } \\
\text { eulittoral rock }\end{array}$ \\
\hline Mid eulittoral & $\begin{array}{l}\text { ELR.NCalTGreA } \\
\text { Non calcareous turf Ulva spp. on exposed mid } \\
\quad \text { eulittoral rock } \\
\text { ELR.CalTGreA } \\
\text { Calcareous turf and Ulva spp. on exposed mid } \\
\quad \text { eulittoral rock }\end{array}$ & $\begin{array}{l}\text { MLR.R Osm } \\
\text { Osmundea pinnatifida on moderately exposed mid } \\
\quad \text { eulittoral rock } \\
\text { MLR.MF MytFves } \\
\text { Mytilus edulis and Fucus vesiculosus on moderately } \\
\quad \text { exposed mid eulittoral rock } \\
\text { MLR.BF FvesB } \\
\text { Fucus vesiculosus and barnacle mosaics on moderately } \\
\text { exposed mid eulittoral rock }\end{array}$ \\
\hline Lower eulittoral & $\begin{array}{l}\text { ELR.CalTNCalTF } \\
\text { Calcareous turf, non clacareous turf and frondose } \\
\text { Corallina elongata, Jania spp. and Haliptylon } \\
\text { spp. on exposed low eulittoral rock } \\
\text { ELR.CalTF } \\
\text { Calcareous turf and Laurencia spp./Osmundea spp. } \\
\text { and Stypocaulon scoparium/Halopteris filicina on } \\
\text { exposed low eulittoral rock }\end{array}$ & $\begin{array}{l}\text { ELR.FR Coff } \\
\text { Corallina officinalis on exposed to moderately exposed } \\
\text { lower eulittoral rock } \\
\text { ELR.FR Him } \\
\text { Himanthalia elongata and red seaweeds on exposed to } \\
\text { moderately exposed lower eulittoral rock } \\
\text { MLR.R Pal } \\
\text { Palmaria palmata on very exposed to moderately exposed } \\
\quad \text { lower eulittoral rock } \\
\text { MLR.R Mas } \\
\text { Mastocarpus stellatus and Chondrus crispus on very } \\
\text { exposed to moderately exposed lower eulittoral rock } \\
\text { MLR.MF MytFR } \\
\text { Mytilus edulis, Fucus serratus and red seaweeds on } \\
\text { moderately exposed lower eulittoral rock } \\
\text { MLR.BF Fser } \\
\text { Fucus serratus on moderately exposed lower eulittoral rock }\end{array}$ \\
\hline
\end{tabular}

the used methodologies are sensible to spatial differences in communities and their association to specific abiotic conditions.
Ongoing implementation of the same methodologies on Graciosa (Azores) and Madeira Islands has proved successful in producing comparative results 
Table 5 Comparison of the subtidal biotopes defined for the Azores and the corresponding ones defined by Connor et al. (2004) for the UK

\begin{tabular}{|c|c|c|}
\hline & Azores & Britain \\
\hline \multirow[t]{14}{*}{ Shallow water } & EIR.CorCalT & IR.MIR.KR.Ldig \\
\hline & $\begin{array}{l}\text { Frondose Corallina elongata, Jania spp. } \\
\text { and Haliptylon spp. and calcareous turf } \\
\text { on exposed shallow infralittoral rock }\end{array}$ & Laminaria digitata on moderately exposed sublittoral fringe rock \\
\hline & EIR.StyCalT & IR.HIR.KFaR.Ala \\
\hline & \multirow{11}{*}{$\begin{array}{l}\text { Stypocaulon scoparium/Halopteris } \\
\text { filicina and calcareous turf on exposed } \\
\text { shallow infralittoral rock }\end{array}$} & Alaria esculenta on exposed sublittoral fringe bedrock \\
\hline & & IR.HIR.KFaR.LhypFa \\
\hline & & $\begin{array}{l}\text { Laminaria hyperborea forest with a faunal cushion (sponges and } \\
\text { polyclinids) and foliose red seaweeds on very exposed upper } \\
\text { infralittoral rock }\end{array}$ \\
\hline & & IR.HIR.KFaR.LhypR \\
\hline & & $\begin{array}{l}\text { Laminaria hyperborea with dense foliose red seaweeds on } \\
\text { exposed infralittoral rock }\end{array}$ \\
\hline & & IR.MIR.KR.Lhyp \\
\hline & & $\begin{array}{l}\text { Laminaria hyperborea and foliose red seaweeds on moderately } \\
\text { exposed infralittoral rock }\end{array}$ \\
\hline & & IR.HIR.KFaR.AlaAnCrSp \\
\hline & & $\begin{array}{l}\text { Alaria esculenta forest with dense anemones and crustose sponges } \\
\text { on extremely exposed infralittoral bedrock }\end{array}$ \\
\hline & & IR.LIR.K.LhypLoch \\
\hline & & $\begin{array}{l}\text { Mixed Laminaria hyperborea and Laminaria ochroleuca forest on } \\
\text { moderately exposed or sheltered infralittoral rock }\end{array}$ \\
\hline \multirow[t]{4}{*}{ Intermediate depth } & EIR.DicSty & Not applicable \\
\hline & $\begin{array}{l}\text { Dictyota spp. and Stypocaulon/Halopteris } \\
\text { on exposed mid depth infralittoral rock }\end{array}$ & \\
\hline & EIR.DicZon & \\
\hline & $\begin{array}{l}\text { Dictyota spp. and Zonaria tournefortii on } \\
\text { exposed mid depth infralittoral rock }\end{array}$ & \\
\hline \multirow[t]{6}{*}{ Deep water } & EIR.Zon & IR.HIR.KFaR.LhypR \\
\hline & \multirow[t]{5}{*}{$\begin{array}{l}\text { Zonaria tournefortii on exposed deep } \\
\text { infralittoral rock }\end{array}$} & $\begin{array}{l}\text { Laminaria hyperborea with dense foliose red seaweeds on } \\
\text { exposed infralittoral rock }\end{array}$ \\
\hline & & IR.HIR.KFaR.FoR \\
\hline & & Foliose red seaweeds on exposed lower infralittoral rock \\
\hline & & IR.MIR.KR.Lhyp \\
\hline & & $\begin{array}{l}\text { Laminaria hyperborea and foliose red seaweeds on moderately } \\
\text { exposed infralittoral rock }\end{array}$ \\
\hline
\end{tabular}

for broad scale characterization studies across regions with similar benthic community structures.

Considering plenty studies that present evidence of the similarity and affinity between benthic communities across archipelagos throughout the macaronesian region (Lawson and Norton 1971; Levring 1974; Elejabeita et al. 1992; Pinedo and Afonso-Carrillo 1992; Reyes and Afonso-Carrillo
1994; Bianchi et al. 1999), it is expected that the methodologies here proposed can be applied to other macaronesian islands.

If the results are to be compared with other geographical regions with wider intertidal platforms, such as the British shores, some adaptations are required though. The use of only three intermediate quantification levels (2, 3 and 4, see Fig. 2) is likely 
to overlook wide intermediate areas where algae community composition changes occur. Therefore, five or more intermediate quantification levels should be adopted to reflect the traditionally called "zonation patterns" of such places. An odd number of intermediate levels shall always be considered to ensure quantification at the level of half distance between low water level and the first algae records on the high shore. In this way the comparability of results between regions is ensured, since the shore quantification levels are set relative to abiotic factors that determine intertidal algae distribution all over the world, namely climatic factors at high shore and hydrodynamic factors at low shore.

Regarding subtidal surveys, in situ quantification procedures pose a serious limitation to the ideal survey design. Ideally, quantification levels should be equally distributed across the entire subtidal distribution of algae communities, which is primarily set by light penetration limits that are variable across geographical regions. Therefore the physical limitation of in situ quantification to $30 \mathrm{~m}$ depth for safety reasons has to be taken into consideration when comparing results between wide regions with differing water bodies' characteristics. Moreover, the adopted methodology was designed to minimize the characteristic blurring of transition zones and provide a clear picture of subtidal algal communities at different levels down to $30 \mathrm{~m}$ depths. However, these aspects must be taken into consideration when comparing results between wide regions with differing water bodies' characteristics, and different communities' structure.

Biotope complexes and biotopes described in the present study (Fig. 3) reflect the general shore zonation patterns observed for the Azores (Tittley et al. 1998; Neto 2000a). Intertidally the intermediate levels 2, 3 and 4 were merged into a major transition zone due to the presence of taxa/ecological categories in common with upper and lower adjacent bands, while subtidally the transition zone resulted from merging depth levels $12-14 \mathrm{~m}$ and $20-22 \mathrm{~m}$ for the same reason.

The comparison between the present biotope classification proposal and that of Connor et al. (2004) summarized in Tables 4 and 5 evidences the structural differences between rocky shore communities in the Azores and the U.K.
In the British Islands the presence of ephemeral green algae is recorded only in places with freshwater or sand-influence, and the intertidal zone is characterized by fucoids, barnacles and mussels communities and kelps (Hawkins and Jones 1992; Connor et al. 1997, 2004), whereas in the Azores algal turfs dominate, as the main structuring feature of intertidal communities (Neto 1992, 2000a, b, 2001; Neto and Tittley 1995; Tittley et al. 1998) with a less rich associated invertebrate fauna. The lower diversity observed on Azorean intertidal biotopes when compared to British ones might be related to their reduced extension that results from very steep shores that are exposed to high wave energy and higher water temperatures. However, the use of broad ecological categories (e.g. turfs) is likely to be responsible for such an apparent low level of diversity in the Azores when compared to U.K. biotopes. Species that characterize British biotopes are easily recognizable by low-skilled surveyors, and for Azorean intertidal communities the equivalently easy to identify community constituents require the use of broad ecological categories as those adopted in the present study. Turfs by themselves encompass a great deal of species (Pryor 1967; Chapman 1955; Neto and Tittley 1995; Tittley et al. 1998) and such a classification implicitly camouflages biodiversity of intertidal communities.

Regarding subtidal communities (Table 5), British shores are generally dominated by large kelps that are characteristic of northern shores, and that have only been recorded at very deep levels in the Azores (Tittley et al. 2001). The sole common characteristic between British and Azorean shores at the subtidal level is the dominance of brown algae.

In what concerns seasonal variation of biotopes, Figs. 3 and 4 show the almost generalized absence of green algae at high intertidal during summer periods, that is likely to be related with the lower wave action and higher desiccation, both responsible for such species disappearance (Connell 1972; Lewis 1972; Underwood and Jernakoff 1981; Hawkins and Hartnoll 1983; Hiscock 1983; Koehl 1986). As indicated in the 'Intertidal Fieldwork' section (see above) transects started at the highest shore level where the first alga was found. In summer periods where high shore green algae are absent, the used methodology implies that sampling overlooks the ELR.GreA zone, 
starting lower on the shore at the transition zone where the green algae component is also absent.

As with spatial characterization and comparison of biotopes, the present approach, proves to be applicable for purposes of seasonal characterization and comparison of biotopes. It proved so by showing sensitivity to seasonal variation in community composition at different shore levels. However, seasonal variation conclusions are based on a comparison between two data sets that were not sampled using the same methodologies (2001 study was a preliminary survey).

Since geographical applicability of the methods proved efficient and are to be further developed, efforts should also be directed at implementing seasonal variation studies, within biotope survey methodology.

\section{Conclusions}

Having passed the test of applicability in three of the islands of the Azores, the presently developed methodologies in which biotope information is integrated with Geographical Information Systems are currently being applied throughout the whole archipelago. Results have already been used by the Environmental Agency of the local government as tool to redefine the existing marine protection area network.

It is now essential to apply such methodologies to other macaronesian islands where communities have a similar structure. This would enable a direct ecological comparison of coastal communities between archipelagos and possibly allow the assessment of the global health of such ecosystems. Some efforts have already been done in Madeira and the results proved reliable, which supports the follow-up of such studies.

Acknowledgements The authors wish to thank Dr. Ian Tittley of the Natural History Museum (London), for general discussions, the firm NERUS for supplying a boat, skipper and some scuba gear when necessary, and João Brum and Pedro Raposeiro for helping with field work. This work was funded by the projects "POCTIMGS/54319/2002 - Biotope Classification, Mapping and Modelling of Azores Littoral Biotopes" and "PARQMAR - Caracterização, ordenamento e gestão de áreas marinhas protegidas na Macaronésia - Os casos do Eco-Parque Marinho do Funchal (Madeira), Gran Canária e Tenerife (Canárias) e Santa Maria (Açores)", and supported also by CIRN-Centro de Investigação de Recursos Naturais (FCT Portugal). The surveys performed in the present study comply with the current laws of Portugal.

\section{References}

Bartsch I, Tittley I (2004) The rocky intertidal biotopes of Helgoland: present and past. Helgol Mar Res 58:289-302

Bianchi CN, Morri C, Sartoni G, Wirtz P (1999) Benthic community zonation on shallow subtidal rocks around Funchal (Ilha da Madeira, NE Atlantic): an update of previous information and comparison with the Mediterranean Sea. Bol Mus Munic Funchal Sup 5:59-80

Borges P (2004) Ambientes litorais nos grupos Central e Oriental do arquipélago dos Açores, conteúdos e dinâmica de microescala. PhD Thesis. Universidade dos Açores, Ponta Delgada, Unpublished

Braun-Blanquet J (1928) Pflanzensoziologie. Grundzüge der Vegetationskunde. Springer-Verlag, Berlin

Chapman G (1955) Aspects of the fauna and flora of the Azores. VI. The density of animal life in the coralline algae zone. Ann Mag Nat Hist 12:398-400

Clarke KR, Warwick RM (2001) Change in marine communities: an approach to statistical analysis and interpretation, 2nd edn. PRIMER-E, Plymouth

Connell JH (1972) Community interactions on marine rocky intertidal shores. Annu Rev Ecol Syst 3:169-192

Connor D, Brazier DP, Hill TO, Northen KO (1997) Marine nature conservation review: marine biotope classification for Britain and Ireland, vol 1, Littoral biotopes, version 97.06. JNCC, Peterborough

Connor DW, Allen JH, Golding N, Howell KL, Lieberknecht LM, Northen KO, Reker JB (2004) The marine habitat classification for Britain and Ireland, version 04.05. Joint Nature Conservation Committee, Peterborough, UK. www.jncc.gov.uk/MarineHabitatClassification (May 6, 2006)

den Hartog C (1959) The epilithic algal communities occurring along the coast of the Netherlands. Wentia 1:1-241

den Hartog C, Segal S (1964) A new classification of the waterplant communities. Acta Bot Neerl 13:367-393

Ducrotoy JP, Simpson SD (2001) Developments in the application of photography to ecological monitoring, with reference to algal beds. Aquatic Conserv Mar Freshw Ecosyst 11:123-135

Elejabeita Y, Reyes J, Afonso-Carrillo J (1992) Algas marinas bentónicas de Punta del Hidalgo, Tenerife (Islas Canarias). Vieraea 21:1-28

Hawkins SJ, Hartnoll RG (1983) Grazing of intertidal algae by marine invertebrates. Oceanogr Mar Biol 21:195-282

Hawkins SJ, Jones HD (1992) Marine field course guide, 1. Rocky shores. Marine Conservation Society, Immel Publishers, London

Hawkins SJ, Burnay LP, Neto AI, Cunha RT, Martins AMF (1990) A description of the zonation patterns of molluscs and other important biota on the south coast of São Miguel, Azores. Açoreana (suppl):21-38

Hiscock K (1983) Water movement. In: Earl R, Erwin DG (eds) The ecology of the shallow sublittoral benthos. Clarendon Press, Oxford 
Hiscock K (ed) (1995) Classification of benthic marine biotopes of the north-east Atlantic. In Proceedings of a BioMar-Life workshop held in Cambridge, 16-18 November 1994. JNCC, Peterborough

Instituto Hidrográfico (1981) Roteiro do Arquipélago dos Açores. PUB. (N)-IH-128-SN, Lisbon

Koehl MAR (1986) Seaweeds in moving water: form and mechanical function. In: Givnish, TJ (ed) On the economy of plant form and function. Cambridge University Press, Cambridge

Lawson GW, Norton TA (1971) Some observations on the littoral and sublittoral zonation of Teneriffe (Canary Isles). Bot Mar 14:116-120

Little C, Kitching JA (1996) The biology of rocky shores. Oxford University Press Inc., New York

Levring $\mathrm{T}$ (1974) The marine algae of the archipelago of Madeira. Bol Mus Munic Funchal 28(125):5-111

Lewis JR (ed) (1972) The ecology of rocky shores. The English Universities Press Ltd., London

Littler MM, Littler DS (1980) The evolution of thallus form and survival strategies in benthic marine macroalgae: field and laboratory tests of a functional form model. Am Nat 116:25-44

Macedo FLWFM (2002) Biótopos do intertidal rochoso da ilha de São Miguel (Açores). Bsc Thesis. Universidade dos Açores, Ponta Delgada, unpublished

Martins GM, Wallenstein FFMM, Álvaro NV, Neto AI, Costa AC (2005) Sampling strategies for biotope definition: minimal sampling area for selected groups of macroinvertebrates in the rocky subtidal of São Miguel, Azores. Helgol Mar Res 59:219-223

Morton B, Britton JC, Martins AMF (eds) (1998) Coastal ecology of the Azores. Sociedade Afonso Chaves, Ponta Delgada

Mumby PJ, Harborne AR (1999) Development of a systematic classification scheme of marine habitats to facilitate regional management and mapping of Caribbean coral reefs. Biol Conserv 88:155-163

Neto AI (1992) Contribution to the taxonomy and ecology of the Azorean benthic marine algae. Biol J Linn Soc 46:163-176

Neto AI (1997) Studies on algal communities of São Miguel, Azores. PhD Thesis. Universidade dos Açores, Ponta Delgada, unpublished

Neto AI (2000a) Ecology and dynamics of two intertidal algal communities on the littoral of the Island of São Miguel (Azores). Hydrobiologia 432:135-147
Neto AI (2000b) Observations on the biology and ecology of selected macroalgae from the littoral of São Miguel (Azores). Bot Mar 43(5):483-498

Neto AI (2001) Macroalgal species diversity and biomass of subtidal communities of São Miguel (Azores). Helgol Mar Res 55:101-111

Neto AI, Tittley I (1995) Structure and zonation of algal turf communities on the Azores: a numerical approach. Bol Mus Munic Funchal Supp 4:487-504

Olenin S, Ducrotoy JP (2006) The concept of biotope in marine ecology and coastal management. Mar Pollut Bull 53:20-29

Pinedo SSM, Afonso-Carrillo J (1992) Algas marinas bentónicas de Puerto de la Cruz (antes Puerto Orotava), Tenerife (Islas Canarias). Vieraea 21:29-60

Pryor J (1967) Intertidal marine algae of São Jorge. Chelsea College Azores Expedition (July-October 1965), Final Report. Chelsea College, London

Reyes JSM, Afonso-Carrillo J (1994) Algas marinas bentónicas de El Médano, S Tenerife (Islas Canarias). Vieraea 23: $15-42$

Stewart JG (1989) Establisment, persistent and dominance of Corallina (Rhodophyta) in algal turf. J Phycol 25:436-446

Tittley I, Neto AI (2000) A provisional classification of algalcharacterised rocky shore biotopes in the Azores. Hydrobiologia 440:19-25

Tittley I, Neto AI, Farnham WF (1998) Marine algae of Flores, Azores: ecology and floristics. Bol Mus Munic Funchal Suppl 5:463-479

Tittley I, Neto AI, Farnham WF, Parente MI (2001) Additions to the marine algal (seaweed) flora of the Azores. Bot Mar 44:215-220

Underwood AJ, Jernakoff P (1981) Effects of interactions between algae and grazing gastropods on the structure of a low-shore intertidal algae community. Oecologia 48:221233

Wallenstein FFMM, Neto AI (2006) Rocky shore biotopes on the Island of São Miguel, Azores. Helgol Mar Res 60:196-206

Wallenstein FFMM, Neto AI, Álvaro NV, Tittley I (in press) Subtidal rocky shore communities of the Azores: developing a biotope survey methodology. J Coast Res (accepted April 12, 2006)

Zacharias MA, Roff JC (2000) A hierarquical ecological approach to conserving marine biodiversity. Conserv Biol 14:1327-1334 